\title{
COLEÇÃO DE JOIAS INSPIRADAS NAS ROMARIAS DO PADRE CÍCERO, EM JUAZEIRO DO NORTE, CEARÁ
}

\author{
Marcia Ferreira da Silva \\ Universidade Federal do Cariri \\ marcyaferreeira@gmail.com \\ Profa. Dra. Ana Neuza Botelho Videla \\ Universidade Federal do Cariri \\ ana.videla@ufca.edu.br
}

Resumo: A proposta deste trabalho é mapear os caminhos percorridos pelos romeiros devotos do Padre Cícero, através do Google Maps. Os desenhos gerados por essa ferramenta serão usados no desenvolvimento de uma coleção de joias. A escolha do tema deu-se pela grande repercussão que o fenômeno da romaria ganhou tanto em termos nacionais, quanto local, transformando a cidade do Juazeiro do Norte em um importante centro religioso do país. Assim sendo, a questão norteadora do presente estudo é no sentido de experimentar as formas geradas pelo mapeamento para projetar uma coleção de joias. Para Nobre (2011), historicamente, a ação da Romaria é contemplada em vários cenários sagrados mundiais. Aqui, na cidade de Juazeiro do Norte, situada no sul do Ceará, Região do Cariri, o foco de atenção ocorreu em torno do milagre operado por Padre Cícero Romão Batista, sacerdote e autor do milagre da hóstia, o qual ocorreu por ocasião de um ritual de comunhão. Sabe-se que o milagre da hóstia, sucedido em 1889, foi um marco que deflagrou as ondas de visitação ao Padre Cícero. Desde então, a cidade de Juazeiro do Norte passou a ser constantemente visitada, transformando-se em um importante centro religioso do país. Os devotos costumam percorrer longas distâncias, muitas vezes a pé, sem medir esforços. Esses fieis passaram a se deslocar para o Juazeiro no intuito de conhecer o Padre Cícero. Segundo Cordeiro (2010), as práticas se perpetuam até os dias atuais, inclusive, com as mesmas intenções, a saber: uns vêm para agradecer milagres alcançados, enquanto outros pedem curas e participam dos rituais eucarísticos, como: missas, celebrações e procissões. Nesse sentido, será o comportamento religioso, bem como a forma com que os romeiros interagem com a cidade e as igrejas católicas, os quais tomaremos por base para o desenvolvimento de uma coleção de joias, ao mesmo tempo em que são plenamente justificáveis. Isto é, esse projeto busca adotar os aspectos da cultura local no desenvolvimento de produto. Em temos de objetivo geral do presente trabalho tem-se o desenvolvimento de adornos inspirados nos caminhos traçados pelos romeiros através do Google Maps. A metodologia adotada para o 
desenvolvimento da coleção partirá de uma adaptação de duas metodologias de design, Buno Munari e Treptow, entre as quais destaca-se as seguintes etapas: a definição do problema, coleta de dados, análises de dados, criatividade, materiais e tecnologias, mix de produtos, mix de coleção, dimensão da coleção, cartela de cores, experimentação e modelagem. Como resultado serão confeccionados dois brincos, um colar e um broche, a partir dos desenhos gerados pela visualização de mapas e rotas das imagens de satélite. Por fim, como a joalheria contemporânea é pautada pela experimentação, no sentido de romper com as convenções e desafiar as tradições da joalheria, conclui-se que a coleção de joias será projetada a partir das práticas religiosas dos romeiros com a adoção de materiais alternativos, como: a palha, madeira, latão, louça e parafina.

Palavras-chave: Design, Romaria, Juazeiro do Norte, Joalheria 